\title{
Violence Against Children and Child Protection (Case Study in Polres Purworejo)
}

\begin{abstract}
Justisia Pamilia Luberty ${ }^{1}$
Abstract. This study aims to explain the factors that cause of cases of violence against children and legal protection of children's data analysis begins with collecting data, reducing the data, presenting data, and the final conclusion. The results showed that the factors that lead to violence against children that occurred in purworejo refer to acts of sexual violence, which resulted in a deep trauma for the victims, as well as their follow-up is handled purworejo police station. Violence against children in purworejo is a case of sexual act that refers to the handling 76E jo Article 82 by Act No. 23 of 2002 on Child Protection. where the victim is a child and the perpetrator comes from within the family and outside the family. Violence against children should look by the community, in education needed either within the family or outside the family, it affects to grow to Consderng children, because every child deserves the affection in the family environment.

Keywords: Violence; Children protection; Families.
\end{abstract}

\section{Introduction}

Violence against children or child abuse a case of very poor action in different parts of the world, every country must find a case like this, one of them in Indonesia, a country rich in ethnic culture and religion can not be separated from the various cases that occur in society.

Since 1990, Indonesia ratified the Convention on the Rights of the Child (CRC). Indonesia is one of 191 countries that have ratified the convention on the rights of children orConvention on the Right of Children in 1990 through Presidential Decree No. 36 in $1990 .^{2}$ By ratifying this Convention, Indonesia has an obligation to fulfill the rights of all children without exception. ${ }^{3}$

Son is also the nation's assets as part of a younger generation, children play a very strategic as succesora nation. In the Indonesian context, the child is the successor to the ideals of national struggle. This strategic role has been recognized by the international community to give birth to a convention that essentially emphasizes the position of the child as a human being who should get the protection of the rights they have. There are still many Indonesian children who are vulnerable to the situation, some facts are quite alarming. Just as children elsewhere in the world, children in Indonesia have suffered violence either within the scope of both internal and external, This resulted in many children who are not aware of conflict with the law, but there are also

\footnotetext{
${ }^{1}$ Student Masters (S-2) of Law Faculty of Law UNISSULA email pamiliajustisia@gmail.com

2 Kemenhukam "Keputusan Presiden Republik Indonesia Nomor 36 Tahun 1990" http://ditjenpp.kemenkumham.go.id/inc/buka.php?czoyNToiZDOxOTAwKzkwJmY9a3AzNiOxOTkwLnBkZi 17 Accessed on July 192018.

${ }^{3}$ Departemen Pendidikan dan Kebudayaan 1988 Kamus Besar Bahasa Indonesia Ed. I Balai Pustaka Jakarta p. 326.
} 
children in conflict with the law as a result of an act criminal who is consciously committed by children.

While in the Qur'An already described that raising children is the responsibility of both parents as stated in At-Tahrim verse 6: Meaning: "O you who believe! Save yourselves and your families from a Fire whose fuel is men and stones, guardian angels are rough and hard, which is not disobedience to Alah of what he told them and always do what they're told ". 4

Crimes of violence against children is a very important issue for victims of crimes of violence are minors, where minors are still in the care of the elderly, children as budding nation and future generations the ideals of the nation should be noted, are protected and guarded from any actions that may be detrimental. ${ }^{5}$

Child protection under Article 1 Paragraph (2) of Act No. 35 of 2014 on the Amendment of Act No. 23 of 2002 on Child Protection are all activities to ensure and protect children and their rights in order to live, grow, develop, and participate optimally in accordance with human dignity, as well as protection of and discrimination. ${ }^{6}$

In connection with the above explanation by rampant violence against children by parents either of the father or the mother, it is a problem that must be followed up through legal channels as crimes of violence against children committed by parents of the victims and sanctions to be adjusted by actors, as well as protection of the victim adanaya. It is exciting to be a material discussion of this thesis in which the filing of the criminal law research related to violence against children committed by parents as well as their protection to victims of violence.

\section{Research Methods}

The research method aims to study one or more of the symptoms, by analyzing them and to hold in depth examination of the facts, to then seek a solution to the problems posed by this fact. ${ }^{7}$ The research method used is as follows:

This study will be prepared using the type of normative juridical research, the research focused on reviewing the application of the rules or norms of positive law. ${ }^{8}$ Normative juridical approach that uses legis positivist conception. It saw identical legal norms made written and enacted by institutions or authorities. This conception of viewing the law as a normative system which is independent, introverted and detached from the real life of society. ${ }^{9}$

\footnotetext{
${ }^{4}$ Muhammad Thalib 199620 Perilaku Durhaka Orang Tua Terhadap Anak Ma'alimul Usrah Media Yogyakarta p. 9.

${ }^{5}$ Wirjono Prodjodikoro 2003 Asas-Asas Hukum Pidana di Indonesia Refika Aditama Ed. 3 Bandung p. 59.

${ }^{6}$ Bambang Poernomo 1993 Asas-Asas Hukum Pidana Ed. 6 Ghalia Indonesia Jakarta p. 129.

${ }^{7}$ Soejono Soekanto 1996 Pengantar Penelitian Hukum UI Press Jakarta p. 2

8Johnny Ibrahim 2006 Teori dan Metodologi Penelitian Hukum Normatif Bayumedia Publishing Malang p. 295.

${ }^{9}$ Ronny Hanitijo Soemitro 1988 Metodologi Penelitian Hukum dan Jurimetri Ghalia Indonesia Jakarta p. 13-14.
} 


\section{Results and Discussion}

\subsection{Children Abuse in Families}

Every life in this world has a core in which a social institution called family. According to Coleman and Cressey, as quoted Zastrow said that meant the family is "a group of social beings who are linked by marriage, which is procreation or adoption where they can live together in a household and be a family". ${ }^{10}$

Family is the main foundation in the growth process of social human from birth until the death of the success of the family (parents) in shaping the child's temperament is very dependent on the subjects in the family.

Violence in the family in general take place in the context of psychological abuse and exploitation. Verbal humiliation in the form of ridicule or profanity often initiate physical violence. This makes the victim feel worthless, unappreciated, unloved. Mistreatment in psychology may interfere with the victim's ability to live up to reality, degrading the image itself and cause to blame herself.Violence in the family has a negative impact on all members of the family, especially for children.

\subsection{Forms of Violence Against Children}

Terry E. Lawson, a child psychiatrist quoted by Rachmat in Baihaqi classify child abuse into four forms, namely, emotional abuse, verbal abuse, physical abuseAnd sexual abuse. While Suharto categorize child abuse into:

- Physical abuse or physical violence, such as torture, beatings and abuse against children.

- Psychological abuse or psychological violence, including rebuking, penyampaikan obscenities, picture books and movies showing pornography to children.

- Sexual abuse or sexual abuse, can be treated pre-sexual contact between children and older adults (image, touch, and so on), as well as the treatment of sexual contact directly.

- Social abuse or social violence, can include neglect and exploitation of children. ${ }^{11}$ Indonesia is a country that has quite a lot of cases of child abuse. Especially sexual violence or sexual abuse suffered by children in Purworejo, Central Java

Table 1.1

PPA Data Validation in 2015-2018

\begin{tabular}{|c|c|c|c|c|}
\hline Year & $\begin{array}{c}\text { Physical } \\
\text { abuse }\end{array}$ & $\begin{array}{c}\text { Psychological } \\
\text { abuse }\end{array}$ & Sexual abuse & Social abuse \\
\hline 2015 & - & - & 26 & - \\
\hline 2016 & - & - & 32 & - \\
\hline 2017 & - & - & 12 & - \\
\hline
\end{tabular}

${ }^{10}$ Miftahul Huda 2009 Sebuah Pengantar Pekerja Sosial dan Kesejahteraan Sosial Pustaka Pelajar Yogyakarta p.218.

${ }^{11}$ Abu Huraerah 2007 Child Abuse Nuansa Bandung p. 47-48. 


\section{8 \\ 11}

Source: The Indonesian National Police Regional Purworejo resort of Central Java, "Data Validation PPA in 2015-2018"

Based on the above table, it can be seen that for 4 years of validated cases of sexual abuse have decreased quite significantly in the last two years. However, cases of sexual abuse in Purworejo, Central Java, had experienced a significant increase as high as 32 cases that have been validated by the police.

\subsection{Factors causes occurrence of violence against children}

Violence against children caused by various factors that influence it. According to Suharto that violence against children is generally caused by internal factors that come from the children themselves maupun external factors are derived from the condition of the family and society, such as:

- The child has a disability, mental retardation, behavioral disorders, autism, children are innocent, have a weak temperament, child ignorance of their rights, children depend on adults.

- Poverty families, parents are unemployed, the income is not enough, many children.

- The split families (broken home), such as divorce, the absence of fathers and mothers for the long term.

- Family psychologically immature, ignorance educate children, parents' expectations are not realistic, unwanted children (unwanted child), children born outside of marriage.

According Soerjono Soekanto, the conceptual framework is a framework that describes the relationship between the concepts of special is a collection of meanings associated with the term to be observed, both in a normative and empirical research. ${ }^{12}$ This was done and intended to prevent misunderstandings in doing research, then here will be explained about the understanding of the principal concepts used in the study, so that will provide restrictions that remain in the interpretation of some of the terms. The terms in question are as follows:

- Child protection is a joint activity aimed at seeking security, procurement and fulfillment of spiritual and physical welfare of children in accordance with their interests and their human rights. ${ }^{13}$

- Legal protection of children is a legal safeguard against the freedoms and rights of children (fundamental rights and freedoms of children) as well as the various interests related to the welfare of children. ${ }^{14}$

- Kids under Article 1 paragraph 1 of Act No. 23 of 2002 on Child Protection is someone who has not aged 18 (eighteen) years, including a child in the womb.

\footnotetext{
${ }^{12}$ Soerjono Soekanto Op. cit. p. 124.

${ }^{13}$ Arif Gosita 2004 Masalah Korban Kejahatan. PT Bhuana Ilmu Poluler Jakarta p. 20.

${ }^{14}$ Barda Nawawi Arief 1998 Beberapa Aspek Kebijakan Penegakan Dan Pengembangan Hukum Pidana. Citra Aditya Bakti Bandung p.156.
} 


\subsection{Solution of Violence Against Children and the Legal Protection for Children.}

Safeguard against child abuse especially in Purworejo get special handling by the Polres Purworejo, where most cases of violence are sexual acts carried out by their own family or outside the family circle, this is of particular concern that should look at the community of Purworejo and the Government of Purworejo so that the implementation of educational programs for the community or Purworejo against violence on children. in this case the family is expected to crime prevention can be achieved significantly. Efforts to protect victims of criminal acts of sexual violence is not merely the duty of the law enforcement agencies, but also an obligation of the community to help restore the condition of the victim in social life.

Efforts protection to rape victims can be divided into two (2), namely:

\subsubsection{Protection By Law}

In general, the positive law in Indonesia was a rule that one aim is to prevent crime. This means, the law also aims to protect people from falling victim to a crime before the crime took place. Under the law, the victim can claim damages or compensation against the convict. Victim protection arrangements in the criminal Positive Law in Indonesia:

- In the Penal Code

Implicitly, the provisions of Article 14c paragraph (1) of the Criminal Code has given protection to victims of crime. The article reads: "In order mentioned in Article 14a except when convicted of fines, then together with a general requirement that those convicted will not commit a crime, the judge may hold a special condition that those convicted will indemnify which occurs because the crime, all or a part of it, which will be determined in the commandment, which is less than the period of the trial. "According to the provisions of Article 14c paragraph (1), as well as Article $14 a$ and $b$ of the criminal Code, the judge can convict with establish special requirements to the sentenced person with a view to replacing the losses caused to the victims.

- In the Code of Criminal Procedure (Criminal Procedure Code) Chapter III About the Merger Case of Compensation, Article $98 \mathrm{~s} / \mathrm{d} 101$ which regulates the remedies provided by the victim by combining criminal and civil cases. It is also a manifestation of the legal protection of victims. So besides the perpetrator has to be punished in kind with his actions, the victim also seek compensation for losses suffered.

\section{Closing}

\subsection{Conclution}

Crimes of violence experienced by children in the City of Purworejo as cases of sexual violence, where children as victims suffer physically and psychologically, it takes quite a long time to recover. Sexual violence in Purworejo every year happen this case handled by law enforcement officials are obliged to provide protection to the victims through laws and regulations. 
Protection of victims of medical aid, as well as adequate law, due process and a fair trial against the perpetrators kejahatan, so that appropriatebasically that is one embodiment of the protection of human rights as well as counterbalanced instrument. From this philosophical basis behind the importance of crime victims (families) protection. Law enforcement officials (police, prosecutors, judges) still treat child victim of sexual violence as an object, not a subject that should be listened to and respected the rights of act. Aparatus (police, judges, prosecutors) do not have the perspective of the child victims of sexual based violence.

\subsection{Suggestion}

The government in this case should have an active role in it as a place for people to be waspadanya it is well within the scope of family internal and external family, the need for programs made by the government in providing education and understanding to every community in Purworejo so that more people understand the importance of a child in family, where the child should receive protection and affection in lingkungannya because it will be a major influence on the development of growing children and this will also positively impact the social life in the community of Purworejo that sexual violence is not increasing each year.

\section{References}

[1] Barda Nawawi Arief 1998 Beberapa Aspek Kebijakan Penegakan Dan Pengembangan Hukum Pidana Citra Aditya Bakti Bandung.

[2] Departemen Pendidikan dan Kebudayaan 1988 Kamus Besar Bahasa Indonesia Balai Pustaka Cet I Jakarta.

[3] Gosita Arif 2004 Masalah Korban Kejahatan PT Bhuana IImu Poluler Jakarta.

[4] Huda Miftahul 2009 Sebuah Pengantar Pekerja Sosial dan Kesejahteraan Sosial Pustaka Pelajar Yogyakarta.

[5] Huraerah Abu 2007 Child Abuse Nuansa Bandung.

[6] Moeljanto 1993 Asas-Asas Hukum Pidana Rineka Cipta Jakarta.

[7] Poernomo Bambang 1993 Asas-Asas Hukum Pidana Ghalia Indonesia Cet 6 Jakarta.

[8] Prodjodikoro Wirjono 2003 Asas-Asas Hukum Pidana di Indonesia Refika Aditama Cet 3 Bandung.

[9] Ronny Hanitijo Soemitro 1988 Metodologi Penelitian Hukum dan Jurimetri Ghalia Indonesia Jakarta

[10] Soekanto Soejono 1996 Pengantar Penelitian Hukum UI Press Jakarta

[11] Ibrahim Johnny 2006 Teori dan Metodologi Penelitian Hukum Normatif Bayumedia Publishing Malang 